\title{
KUALITAS MINYAK BUNGA MATAHARI KOMERSIAL DAN MINYAK HASIL EKSTRAKSI BIJI BUNGA MATAHARI (Helianthus annuus L.)
}

\author{
Dewa G. Katja ${ }^{1)}$ \\ ${ }^{1)}$ Program Studi Kimia FMIPA Universitas Sam Ratulangi \\ Jl. Kampus Unsrat Manado, 95115 \\ dewakatja@yahoo.com
}

\begin{abstract}
ABSTRAK
Minyak komersial dan minyak hasil ekstrasi dari biji bunga matahari melalui uji kadar air, kadar asam lemak bebas, bilangan peroksida. Analisis hasil ekstrak biji bunga matahari diperoleh kadar air $0,43 \%$, kadar asam lemak bebas $0,47 \%$ dan bilangan persoksida $5,22 \mathrm{mek} / \mathrm{kg}$. analisis minyak komersial diperoleh kadar air 0,21\%, kadar asam lemak bebas $0,28 \%$ dan bilangan peroksida 4,18 mek/kg. Hasil analisis dengan kromatografi gas kedua sampel menunjukkan kadar asam lemak bebas berbeda. Berdasarkan uji kualitas yang dilakukan terhadap kedua sampel yang dianalisis terdapat hasil yang diperoleh tidak memenuhi syarat yang ditentukan yakni kadar asam lemak bebas $0,08 \%$ dan bilangan peroksida $2 \mathrm{mek} / \mathrm{kg}$.
\end{abstract}

Kata kunci: Asam lemak bebas, bilangan proksida, minyak biji bunga matahari

\section{QUALITY OF COMMERCIAL SUNFLOWER OIL AND OIL EXTRACTION SEEDS SUNFLOWER (Helianthus annuus L.)}

\begin{abstract}
Experimental study of analyzing the extract oil from sunflower seed compare with the commercial sunflower seed oil according to the company standard which includes determining of moisture content, free fatty acid content, peroxide value and the fatty acids compositions is reported in this paper. The result show that the moisture content of the extract oil is $0,43 \%$, free fatly acid content is $0,47 \%$, and the peroxide value is $5,22 \% \mathrm{mek} / \mathrm{Kg}$. For the commercial sunflower seed oil company product that is $0,21 \%$ for the moisture, free fatty acid is $0,28 \%$ and the peroxide value is $4,89 \mathrm{mek} / \mathrm{Kg}$. The gas chromatography analysis indicated that the most fatty acid from both samples is linoleic acid. The quality of the extract sunflower seed oil has not been improved to conform with the commercial quality according to the company standard, that is $0,08 \%$ for the free fatty acid and $2 \mathrm{mek} / \mathrm{Kg}$ for the peroxide value.
\end{abstract}

Keywords: Free fatty acid, peroxide value, sunflower seeds oil

\section{PENDAHULUAN}

Bunga matahari (Helianthus annuus L.) termasuk famili compositae.Tanaman bunga matahari berasal dari Meksiko dan Peru Amerika Latin. Di Indonesia, bunga matahari sudah di teliti sejak tahun 1970. Pada mulanya tanaman bunga matahari dikenal sebagai tanaman hias, kini manfaatnya semakin luas. Salah satu produk utama bunga matahari adalah biji-bijinya yang diolah sebagai bahan baku industri makanan berupa kwaci dan penghasil minyak nabati yang dibutuhkan dalam isdustri minyak (Atjung, 1981)

Minyak biji bunga matahari merupakan salah satu jenis minyak nabati yangpegembangannya masih terbatas di Indonesia. Beberapa industri di Indonesia masih harus mengimpor minyak biji bunga matahari, tingginya impor minyak biji bunga matahari di Indonesia disebabkan kurangnya pasokan dari dalam negeri, kualitas yang belum memadai, dan kontinuitas hasil yang belum dapat diandalkan (Guenther, 1990). 
Komposisi minyak biji bunga matahari berkisar antara 23-45\%. Minyak biji bunga matahari mengandung asam linoleat 44-72\% dan asam oleat $11,7 \%$. Minyak biji bunga matahari digunakan untuk berbagai keperluan seperti minyak goreng, pembuatan margarine bahan baku kosmetik, dan obat-obatan, selain itu bungkil atau ampas hasil pemerasan minyak mengandung $13-20 \%$ protein, yang dapat dimanfaatkan sebagai pakan ternak. Misalnya biji bunga matahari termasuk golongan minyak rendah kolesterol menyaingi minyak jagung, minyak kacang tanah dan minyak kadelai, sehingga sangat baik untuk kesehatan (Rukmana, 2004).

Minyak dan lemak dapat mengalami penurunan kualitas baik waktu proses maupun saat penyimpanan. Kerusakan minyak dan lemak yang utama adalah timbulnya bau dan rasa tengik yang disebut ketengikan. Hal ini disebabkan oleh proses hidrolisis dan oksidasi akan terbentuk senyawa-senyawa yang dapat menurunkan kualitas dari minyak dan lemak. Parameter yang umum dipakai untuk menentukan kualitas minyak adalah kadar air,kadar asam lemak bebas dan bilangan peroksida (Beck dan Zapsalis, 1986).

Berdasarkan uraian terseabut diatas,peneliti mengekstrak minyak dari biji bunga matahari yang siap panen, dilanjutkan dengan menganalisis kualitas minyak asal ekstraksi dan membandingkannya denganminyak biji bunga matahari komersial dengan menentukan kadar air, kadar asam lemak bebas, bilangan peroksida serta menurunkan komposisi asam-asam lemak.

Tujuan penelitian ini adalah memberikan informasi tentang kualitas minyak biji bunga matahari hasil ektraksi dan minyak biji bunga matahari komersial dengan menghitung kadar air, kadar asam lemak bebas, bilangan peroksida serta menetukan komposisi asam-asam lemak.

\section{METODOLOGI PENELITIAN}

Penelitian ini dilaksanakan di Laboratorium Kimia Lanjut I dan II FMIPA UNSRAT Manado. Pembuatan dan analisis metal ester asam lemak dilakukan di Laboratorium PAU IPB Bogor. Pelaksanaannya pada bulan November 2011 - Januari 2012.
Bahan-bahan yang digunakan dalam penelitian ini adalah minyak biji bunga matahari komersial (minyak hasil impor dari Filipina yang digunakan sebagai medium dalam ikan kaleng, pada industri pengalengan ikan), biji bunga matahari, petroleum eter teknis, alcohol 96\% teknis, fenolftalein (PP), natrium hidroksida $(\mathrm{NaOH})$, asam oksalat $\left(\mathrm{C}_{2} \mathrm{H}_{2} \mathrm{O}_{4} \cdot 2 \mathrm{H}_{2} \mathrm{O}\right)$, asam asetat $\left(\mathrm{CH}_{3} \mathrm{COOH}\right)$ glasial, klorofom $\left(\mathrm{CHCI}_{3}\right)$, kalium iodide (KI), natrium tiosulfat pentahidrat $\left(\mathrm{Na}_{2} \mathrm{~S}_{2} \mathrm{O}_{3} .5 \mathrm{H}_{2} \mathrm{O}\right)$ natrium karbonat $\left(\mathrm{Na}_{2} \mathrm{CO}_{3}\right)$, kalium iodat $\left(\mathrm{KIO}_{3}\right)$ asam klorida $(\mathrm{HCI})$, pati, kertas saring dan akuades. Alat-alat yang digunakan dalam penelitian ini adalah seperangkat alat soklet, mantel pemanas, cawan, oven, desikator, alat titrasi, neraca analitik, blender kering dan peralatan gelas kimia.

Penelitian ini dilakukan melalui tahap pendahuluan dan tahap lanjutan.Tahap pendahuluan meliputi persiapan sampel. Dan tahap lanjutan meliputi pembuatan pelarut petroleum eter, kestraksi minyak, dan analisis sampel minyak (kadar air, kadar asam lemak bebas, bilangan peroksida, dan komposisi asam-asam lemak).

\section{Tahap Pendahuluan}

Perlakuan pendahuluan meliputi pembersihan biji bunga matahari dari kotoran, pengeringan dengan udara terbuka, penghalusan dengan menggunakan blender kering.

\section{Tahap Lanjutan}

Petroleum eter diperlukan dari proses penyulingan bensin fraksi $40-60^{\circ} \mathrm{C}$ selama 57 jam menggunakan alat destilasi fraksinasi

Ekstraksi minyak biji matahari dilakukan dengan metode eksraksi pelarut yang menggunakan alat soxlet. Ditimbang \pm $40 \mathrm{~g}$ Biji bunga matahari yang telah halus kemudian dibungkus dengan kertas saring yang berbentuk silinder, pada bagian bawah dan bagian atas ditutup dengan kapas, selanjutnya dimasukkan ke dalam seperangkat alat soklet dan diekstrak dengan pelarut petroleum eter sebanyak $250 \mathrm{ml}$ selama 4 jam. Minyak kasar hasil ekstraksi dipisahkan dari pelarut dengan cara diuapkan dari minyak yang diperoleh ditimbang. Hal yang sama dilakukan sebanyak tiga kali (Sudarmadji, dkk., 1984). Penentuan persen 
kadar minyak dihitung dengan persamaan berikut:

$$
\begin{aligned}
\text { \%adar Minyak } & =\frac{\mathrm{W}_{1}-\mathrm{W}}{\mathrm{W}_{\mathrm{o}}} \times 100 \% \ldots(1) \\
\text { Dimana }: \mathrm{W}_{\mathrm{o}}= & \text { Berat sampel } \\
\mathrm{W}= & \text { Berat labu kosong } \\
\mathrm{W}_{1}= & \text { Barat labu + minyak hasil } \\
& \text { ekstraksi }
\end{aligned}
$$

Masing-masing sampel minyak dianalisi kualitasnya yang mencakup kadar air, kadar asam lemak bebas, bilangan peroksida (Sudarmadji, dkk., 1984). Ditentukan pula komposisi asam-asam lemak dalam minyak biji bunga matahari menggunakan kromatografi gas.

Kadar air dalam minyak dianalisis dengan cara ditimbang sebanyak $\quad \pm 5 \mathrm{~g}$ sampel minyak dalam cawan yang telah diketahui beratnya dan dimasukkan ke dalam oven dengan suhu $105^{\circ} \mathrm{C}$ selama 15 menit. Selanjutnya cawan yang berisi minyak di timbang sampai beroleh berat konstan. Penentuan persen kadar air dihitung dengan persamaan berikut :

$$
\% \text { Kadar air }=\frac{\left(\mathrm{W}+\mathrm{W}_{\mathrm{o}}\right)-\mathrm{W}_{1}}{\mathrm{~W}_{\mathrm{o}}} \times 100 \% \ldots
$$

Dimana : $\mathrm{W}_{\mathrm{o}}=$ Berat awal minyak

$\mathrm{W}=$ Beratcawan

$\mathrm{W}_{1}=$ Barat cawan dan berat minyak dan berat minyak setelah dikeringkan

Dalam analisis kadar asam lemak bebas, ditimbang sebanyak $\pm 2,82 \mathrm{~g}$ sampel minyak dalam Erlenmeyer $250 \mathrm{~mL}$ dan di tambahkan $5 \mathrm{~mL}$ alcohol yang panas dan 4 tetes fenolftalein, kemudian dititrasi dengan larutan $\mathrm{NaOH}$ 0,1 $\mathrm{N}$ sampai berwarna merah jambu yang tidak hilang selama 30 detik. Kadar asam lemak bebas dihitung dari hasil rata-rata tiga kali ulangan.

$$
\% \text { Kadar asam lemak beba }=\frac{\mathrm{N} \times \mathrm{V} \text { x MM }}{\mathrm{W} \times 1000} \times 100 \%
$$

Dimana $: \mathrm{N}=$ Normalitas $\mathrm{NaOH}$

$$
\begin{aligned}
& \mathrm{V}=\text { Volume } \mathrm{NaOH} \text { yang terpakai } \\
& \mathrm{W}=\text { Barat sampel } \\
& \mathrm{MM}=\text { Berat molekul } \mathrm{C}_{17} \mathrm{H}_{31} \mathrm{COOH} \\
& \text { (208) }
\end{aligned}
$$

Parameter kualitas minyak berikutnya yaitu bilangan peroksida Analisi bilangan peroksida dilakukan dengan cara ditimbang sebanayak $\pm 5,00 \mathrm{~g}$ sampel minyak dalam
Erlenmeyer $250 \mathrm{~mL}$ dan ditambahkan $30 \mathrm{~mL}$ larutan asam asetat glacial - kloroform (3:2). Larutan dikocok sampai bahan terlarut semua, kemudian ditambahkan $0,5 \mathrm{~mL}$ larutan jenuh KI. Larutan didiamkan selama 1 menit dan kadangkala dokocok, kemudian ditambahkan $30 \mathrm{~mL}$ akuades. Selanjutnya dititrasi dengan larutan $\mathrm{Na}_{2} \mathrm{~S}_{2} \mathrm{O}_{3} 0,1 \mathrm{~N}$ sampai warna kuning hampir hilang. Ditambahkan $0,5 \mathrm{~mL}$ larutan pati $1 \%$ dan dititrasi kembali sampai warna biru mulai hilang.Bilangan peroksida dihitung dari hasil rata-rata tiga kali ulangan.

$$
\text { Bilangan peroksida }=\frac{\mathrm{mL} \mathrm{Na} 2 \mathrm{~S} 203 \times \mathrm{N} \text { thio } \times 1000}{\text { Berat sampel }(\mathrm{g})} \ldots
$$

Komposisi asam-asam lemak dalam binyak biji bunga matahari dianalisis dengan metode kromatografi gas.Pada tahap ini cuplikan yang dianalisis telah melalui derivatisasi yaitu minyak biji bunga matahari diesterfikasi terlebih dahulu menggunakan methanol.Esterifikasi dilakukan menggunakan metode dari IUPAC yang dilaksanakan di PAU IPB Bogor.Konsentrasi asam-asam lemak dalam minyak biji bunga matahari dihitung dengan membandingkan waktu retensi puncak-puncak sampel pada kromatogram (Lampiran 1 dan 2) dengan waktu retensi senyawa berstandar (Lampiran 3) dengan persamaan berikut:

Perhitungan konsentrasi asam lemak

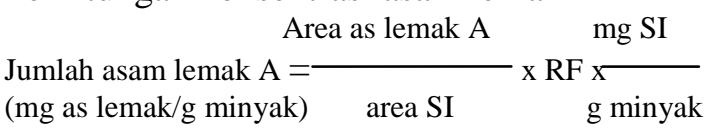

Nilai RF dihitung dari kromatogam standar FAME

$\mathrm{RF}$ as lemak $\mathrm{A}=\frac{\text { Area SI Konsentrasi as lemak A dari standar }}{\text { Konsentrasi SI }} \mathrm{X} \frac{\text { Area as lemak A dari standar }}{\text {. }}$ .... (6)

Dalam hal ini :

Berat Sampel Minyak Hasil Ekstrasi :

SpL A-1 = 0,1133 g ; Spl A-2 = 0,1222 g

Berat Sampel Minyak Standar Perusahaan :

SpL B-1 $=0,1209 \mathrm{~g} ;$ Spl B-2 $=0,1126 \mathrm{~g}$

Berat Sampel Internal (C:17) $=1,3867 \mathrm{mg}$

\section{HASIL DAN PEMBAHASAN}

\section{Kadar Minyak}

Kadar minyak biji bunga matahari hasil ekstraksi dengan menggunakan pelarut petroleum eter dapat dilihat pada table 1 . 
Tabel 1: Kadar minyak (\%) hasil ekstraksi biji bunga matahjari (Oil rate (\%) result of extract of sunflower seed).

\begin{tabular}{|c|c|c|c|}
\hline \multicolumn{2}{|c|}{ Berat (g) } & \multirow{2}{*}{$\begin{array}{c}\text { Kadar } \\
\text { minyak } \\
(\%)\end{array}$} & $\begin{array}{c}\text { Rata- } \\
\text { rata } \\
(\%)\end{array}$ \\
\hline Sampel & $\begin{array}{c}\text { Minyak } \\
\text { kasar }\end{array}$ & \multirow{2}{*}{34,45} \\
\hline 40,2 & 12,87 & 32,01 & \\
\hline 43,03 & 15,43 & 33,52 & \\
\hline
\end{tabular}

Berdasarkan hasil pengamatan, biji bunga matahari yang diekstrak selam 4 jam dengan metode soklet menghasilkan minyak berwarna kuning dengan rendemen rata-rata $32,45 \%$. Nilai rendemen ini menurut Guenther (1990) bervariasi karena dipengaruhi oleh beberapa factor, misalnya tempat tumbauh, varietas, lama penyulingan, dan perlakuan bahan.

Menurut bernasconi, dkk., (1995) dalam ekstraksi minyak atau lemak pelarut berperan penting dalam menentukan jumlah dari minyak atau lemak yang dihasilkan. Petroleum eter merupakan bahan pelarut lipida non polar yang paling banyak digunakan dengan alasan lebih selekatif terhadap lipida non polar, kurang berbahaya terhadap resiko kebakaran dan ledakan, dan harganya relatif murah.

\section{Kadar air}

Hasil perhitungan kadar air (persamaan 2) untuk minyak yang diperoleh dari ekstraksi biji bunga matahari dengan menggunakan pelarut petroleum eter dan sampel minyak biji bunga matahari komersial dapat dilihat pada table 2 .

Table 2.Hasil perhitungan kadar air untuk sampel minyak biji bunga matahari (Result of rate calculation irrigate for the sampel of binyak of sunflower seed).

\begin{tabular}{|c|l|c|c|c|c|}
\hline \multirow{2}{*}{ No } & \multicolumn{1}{|c|}{$\begin{array}{c}\text { Jenis } \\
\text { Sampel }\end{array}$} & \multicolumn{4}{|c|}{ Kadar Air (\%) } \\
\cline { 3 - 6 } & $\begin{array}{c}\text { Ulang } \\
\text { an I }\end{array}$ & $\begin{array}{c}\text { Ulang } \\
\text { an II }\end{array}$ & $\begin{array}{c}\text { Ulang } \\
\text { an III }\end{array}$ & $\begin{array}{c}\text { Rata } \\
\text {-rata }\end{array}$ \\
\hline 1. & $\begin{array}{l}\text { Minyak } \\
\text { hasil } \\
\text { Ekstrasi }\end{array}$ & 0,45 & 0,42 & 0,43 & 0,43 \\
\hline 2. & $\begin{array}{l}\text { Minyak } \\
\text { komersial }\end{array}$ & 0,22 & 0,22 & 0,19 & 0,21 \\
\hline
\end{tabular}

Tingginya kadar air untuk sampel minyak diperoleh dari hasil ekstrasi biji bunga matahari kemungkinan disebabkan karena lamanya penyimpanan sampel minyak sebelum dianalisis. Menurut Winarno (1980), kadar air pada permukaan bahan dipengaruhi oleh kelembaban udara disekitarnya tinggi, akan terjadi penyerapan uap air dari udara sehingga bahan menjadi lembab atau kadar airnya menjadi lebih tinggi.

Perhitungan kadar air bertujuan untuk mengetahui kadarair dalam sampel minyak biji bunga matahari karena kadar air dalam suatu bahan dapat mempengaruhi kualitas minyak. Ketaren (1986) menyatakan bahwa kadar air yang rendah memperkecil terjadinya proses hidrolisis, sehingga mengurangi terbentuknya asam lemak bebas dan gliserol yang menyebabkan ketengikan minyak.

\section{Kadar Asam Lemak Bebas}

Hasil perhitungan kadar asam lemak(persamaan 3) untuk sampel minyak yang diperoleh dari ekstrasi biji bunga matahari dengan menggunakan pelarut petroleum eter dan sampel biji bunga matahari komersial dapat dilihat pada tabel 3 .

Tabel 3 : hasil perhitungan kadar asam lemak bebas untuk sampel minyak biji bunga matahari (Result of acid contents calculation free fat for the sampel of oil ofsunflower seed).

\begin{tabular}{|l|l|c|c|c|c|}
\hline \multirow{2}{*}{ No } & \multirow{2}{*}{$\begin{array}{c}\text { Jenis } \\
\text { Sampel }\end{array}$} & \multicolumn{4}{|c|}{ Kadar Asam Lemak Bebas (\%) } \\
\cline { 3 - 6 } & an I & $\begin{array}{c}\text { Ulang } \\
\text { an II }\end{array}$ & $\begin{array}{c}\text { Ulang } \\
\text { an II }\end{array}$ & $\begin{array}{c}\text { Rata } \\
\text {-rata }\end{array}$ \\
\hline 1 & $\begin{array}{l}\text { Minyak } \\
\text { hasil } \\
\text { Ekstrasi }\end{array}$ & 0,45 & 0,46 & 0,51 & 0,47 \\
\hline 2 & $\begin{array}{l}\text { Minyak } \\
\text { Komersi } \\
\text { al }\end{array}$ & 0,27 & 0,33 & 0,26 & 0,28 \\
\hline
\end{tabular}

Tingginya kadar asam lemak bebas pada minyak biji bunga matahari diduga karena adanya reaksi hidrolis. Pada sampel minyak hidrolis dapat disebabkan oleh lipase yang berasal dari mikroorganisme, serta adanya sejumlah air yang terkandung dalam minyak tersebut, dengan adanya air minyak dan lemak akan mudah terhidrolisis menjadi gliserol dan asam lemak bebas (Ketaren, 1986).

Selama proses ekstrasi, minyak dan lemak juga dapat terhidrolisis, pemanasan yang digunakan selama proses ekstrasi dapat mengakibatkan enzim lipase yang secara alami terdapat dalam jaringan tanaman 
menjadi aktif dan menyebabkan adanya pembentukan asam lemak bebas dari lemak tanaman (Winarno, 1997)

Berdasarkan hasil perhitungan kadar asam lemak bebas terhadap sampel minyak biji bunga matahari hasil ekstrasi dibandingkan dengan kualitas minyak biji bunga matahari yang ditetapkan oleh perusahaan yaitu $0,08 \%$. Hal ini berarti bahwa minyak biji bunga matahari hasil ekstrasi belum memenuhi persyaratan.

\section{Bilangan Peroksida}

Hasil perhitungan bilangan peroksida (persamaan 4) untuk sampel minyak yang diperoleh dari ekstrasi biji bunga matahari dengan menggunakan pelarut petroleum eter dan sampel biji bunga matahari komersial dapat dilihat pada tabel 4 .

Tabel 4. Hasil perhitungan bilangan peroksida untuk sampel minyak biji bunga matahari.

\begin{tabular}{|c|c|c|c|c|c|}
\hline \multirow{2}{*}{$\begin{array}{c}\mathrm{N} \\
\mathrm{o}\end{array}$} & \multirow{2}{*}{$\begin{array}{c}\text { Jenis } \\
\text { Sampel }\end{array}$} & $\begin{array}{c}\text { Ulanga } \\
\text { n I }\end{array}$ & $\begin{array}{c}\text { Ulanga } \\
\text { n II }\end{array}$ & $\begin{array}{c}\text { Ulanga } \\
\text { n II }\end{array}$ & $\begin{array}{c}\text { Rata } \\
\text {-rata }\end{array}$ \\
\hline 1 & $\begin{array}{l}\text { Minyak } \\
\text { hasil } \\
\text { Ekstrasi }\end{array}$ & 5,08 & 5,29 & 5,29 & 5,22 \\
\hline 2 & $\begin{array}{l}\text { Minyak } \\
\text { Komersi } \\
\text { al }\end{array}$ & 4,48 & 5,09 & 5,08 & 4,89 \\
\hline
\end{tabular}

Tingginya bilangan peroksida kemungkinan disebabkan oleh kontak bahan dengan udaradan lamanya penyimpanan, sehingga reaksi oksidasi dapat berlangsung. Menurut Ketaren (1986) proses oksidasi terjadi pada suhu kamar dan selama pengolahan menggunakan suhu tinggi.

Berdasarkan hasil perhitungan peroksida terdapat sampel minyak biji bunga matahari hasil ekstrasi, dibandingkan dengan kualitas minyak biji bunga matahari yang ditetapkan oleh perusahaan yaitu $2 \mathrm{mek} / \mathrm{kg}$. Hal ini berarti bahwa minyak biji bunga matahari hasil ekstrasi belum memenuhi persyaratan.

\section{Komposisi Asam-asam Lemak dalam Minyak Biji Bunga Matahari}

Data hasil analisis komposisi asam lemak untuk sampel minyak yang diperoleh dari ekstrasi biji bunga matahari dan sampel minyak biji bunga matahari komersial dapat dilihat pada tabel 5 dan 6 .
Tabel 5. Hasil perhitungan kadar metal ester asam lemak untuk sampel minyak biji bunga matahari hasil ekstraksi.

\begin{tabular}{|l|l|c|c|c|c|}
\hline No & \multicolumn{1}{|c|}{$\begin{array}{c}\text { Asam } \\
\text { lemak }\end{array}$} & $\begin{array}{c}\mathrm{Spl} \\
\mathrm{Ag}-1\end{array}$ & $\begin{array}{c}\mathrm{Spl} \\
\mathrm{A}-2 \\
\mathrm{Mg} / \mathrm{g}\end{array}$ & $\begin{array}{c}\text { Rata- } \\
\text { rata } \\
\mathrm{Mg} / \mathrm{g}\end{array}$ & $\begin{array}{c}\text { Rata- } \\
\text { rata } \\
\mathrm{Mg} / 10 \\
0 \mathrm{mg}\end{array}$ \\
\hline 1 & ${\text { Laurat } \mathrm{C}_{12}}$ & 3,79 & 0,28 & 2,04 & 0,20 \\
\hline 2 & ${\text { Miristat } \mathrm{C}_{14}}$ & 4,15 & 1,24 & 2,70 & 0,27 \\
\hline 3 & ${\text { Palmitat } \mathrm{C}_{16}}$ & 50,09 & 49,72 & 49,90 & 4,99 \\
\hline 4 & $\begin{array}{l}\text { Palmitoleat } \\
\mathrm{C}_{16.1}\end{array}$ & 1,75 & 1,42 & 1,20 & 0,12 \\
\hline 5 & $\begin{array}{l}\text { Heptadekan } \\
\text { oat } \mathrm{C}_{17}\end{array}$ & 12,23 & 11,34 & 11,79 & 1,17 \\
\hline 6 & ${\text { Stearat } \mathrm{C}_{18}}$ & 1,97 & 1,90 & 1,93 & 0,19 \\
\hline 7 & $\begin{array}{l}\text { Elaidat } \mathrm{C}_{18.1} \\
296,1\end{array}$ & 767,4 & 331,8 & 33,18 \\
\hline 8 & $\begin{array}{l}\text { Linoleat } \\
\mathrm{C}_{18.2}\end{array}$ & 339,4 & 399,8 & 369,6 & 36,96 \\
1 & 1 & 1 & - \\
\hline 9 & $\begin{array}{l}\text { Linolenat } \\
\mathrm{C}_{18.3}\end{array}$ & 1,71 & - & - & - \\
\hline 10 & $\begin{array}{l}\text { Arakidat } \\
\mathrm{C}_{20.0}\end{array}$ & 1,43 & 1,80 & 1,16 & 0,16 \\
\hline 11 & $\begin{array}{l}\text { Eicosanoat } \\
\mathrm{C}_{20.1}\end{array}$ & 1,61 & 1,97 & 1,79 & 0,17 \\
\hline 12 & $\begin{array}{l}\text { Beheneat } \\
\mathrm{C}_{22.0}\end{array}$ & 4,40 & 6,21 & 5,31 & 0,53 \\
\hline 13 & ${\text { Eruric } \mathrm{C}_{22.1}}$ & 1,04 & 1,70 & 1,37 & 0,13 \\
\hline
\end{tabular}

Tabel 6. Hasil perhitungan kadar metil ester asam lemak untuk sampel minyak biji bunga matahari komersial (result of calculation of sour ether methyl rate of fat for the sampel of commercial sunflower seed oil).

\begin{tabular}{|l|l|c|c|c|c|}
\hline No & \multicolumn{1}{|c|}{$\begin{array}{c}\text { Asam } \\
\text { lemak }\end{array}$} & $\begin{array}{c}\mathrm{Spl} \\
\mathrm{B}-1 \\
\mathrm{Mg} / \mathrm{g}\end{array}$ & $\begin{array}{c}\mathrm{Spl} \\
\mathrm{B}-2 \\
\mathrm{Mg} / \mathrm{g}\end{array}$ & $\begin{array}{c}\text { Rata- } \\
\text { rata } \\
\mathrm{Mg} / \mathrm{g}\end{array}$ & $\begin{array}{c}\text { Rata- } \\
\text { rata } \\
\mathrm{Mg} / 10 \\
0 \mathrm{mg}\end{array}$ \\
\hline 1 & Miristat $\mathrm{C}_{14}$ & 0,58 & 0,57 & 0,57 & 0,05 \\
\hline 2 & $\begin{array}{l}\text { Palmitat } \\
\mathrm{C}_{16}\end{array}$ & 52,79 & 54,41 & 53,60 & 5,36 \\
\hline 3 & $\begin{array}{l}\text { Palmitoleat } \\
\mathrm{C}_{16.1}\end{array}$ & 0,53 & 0,55 & 0,54 & 0,05 \\
\hline 4 & $\begin{array}{l}\text { Heptadeka } \\
\text { noat } \mathrm{C}_{17}\end{array}$ & 11,46 & 12,31 & 11,89 & 1,18 \\
\hline 5 & ${\text { Stearat } \mathrm{C}_{18}}$ & 26,87 & 4,66 & 15,77 & 1,57 \\
\hline 6 & $\begin{array}{l}\text { Elaidat } \\
\mathrm{C}_{18.1}\end{array}$ & 149,4 & 178,5 & 163,9 & 16,39 \\
\hline 7 & $\begin{array}{l}\text { Linoleat } \\
\mathrm{C}_{18.2}\end{array}$ & 673,6 & 683,5 & 678,6 & 67,86 \\
\hline 8 & $\begin{array}{l}\text { Linolenat } \\
\mathrm{C}_{18.3}\end{array}$ & 10,63 & 9,93 & 10,28 & 1,02 \\
\hline 9 & $\begin{array}{l}\text { Arakidat } \\
\mathrm{C}_{20.0}\end{array}$ & 1,41 & 2,27 & 1,84 & 0,18 \\
\hline 10 & $\begin{array}{l}\text { Eicosanoat } \\
\mathrm{C}_{20.1}\end{array}$ & 1,09 & 2,47 & 1,78 & 0,17 \\
\hline 11 & $\begin{array}{l}\text { Beheneat } \\
\mathrm{C}_{22.0}\end{array}$ & 5,44 & 4,45 & 4,95 & 0,49 \\
\hline 12 & Eruric $\mathrm{C}_{22.1}$ & 0,34 & 0,68 & 0,51 & 0,05 \\
\hline & & & & \\
\hline
\end{tabular}

Dari hasil analisis kromatografi gas dua sampel tersebut menunjukkan komposisi asam lemak yang terdapat dalam minyak biji 
bunga matahari berbeda. Menurut Ketaren (1986), bahwa komposisi atau kadar asam lemak berbeda-beda, hal ini disebabkan oleh perbedaan sumber iklim, keadaan tempat tumbuh dan pengolahan.

Atjung (1981) menyatakan bahwa, minyak dan lemak dari sumber tertentu mempunyai ciri khas yang berbeda dari sumber lainnya, tergantung pada komposisi dan distribusi asam lemak pada molekul trigliseridanya. Komposisi termasuk panjang rantai, kejenuhan dan ketidak jenuhan serta distribusi asam lemak pada molekul gliserol yang sangat mempengaruhi sifat-sifat lemak dan minyak baik fisika maupun kimia.

\section{KESIMPULAN DAN SARAN}

\section{Kesimpulan}

1. Berdasarkan analisiskualitas sampel minyak biji bunga matahari hasil ekstrasi, dibandingkan dengan standar kualitas minyak biji bunga matahari komersial oleh perusahaan, hasilnya belum memenuhi persyaratan yang ditetapkan.

2. Hasil analisis kromatografi gas dua sampel tersebut menujukkan kadar asam lemak yang berbeda. Dari hasil analisis diperoleh komposisi asam lemak yang terbesar adalah asam linoleat.

\section{Saran}

Perlu dilakukan permurnian pada minyak biji bunga matahari hasil ekstrasi, agar diperoleh kualitas minyak yang baik, sesuai dengan standar yang ditetapkan oleh perusahaan.

\section{DAFTAR PUSTAKA}

Atjung. 1981. Tanaman Yang Menghasilkan Minyak, Tepung Gula. Penerbit. Yasaguna, Jakarta.

Beck, R.A., dan C. Zapsalis. 1986. Food Chemistry and Nutritional Biochemistry. Macmillan Publishing Company, New York.
Bernasconi, G., H. Gerster, H. Hauser, H. Staubel dan E. Schneiter. 1995. Teknologi Kimia. Jilid 2. Terjemahan Lienda Handojo. P.T. Pranya Paramita, Jakarta.

Guenther, E. 1990. Minyak Atsiri. Jilid I. UIPress, Jakarta.

IUPAC. 1987. Standard Methods for the Analysis of Oils, Fats and Dervates $7^{\text {th }}$ Edition. International Union Pure and Aplied Chemistry, Consorcium on Oils, Fats and Derivates. Backwell Scientifiets Publications Oxford, England.

Ketaren, S. 1986. Pengantar Teknologi Minyak dan Lamak Pangan. UI-Press. Jakarta.

Rukmana, R. 2004. Budidaya Bunga Matahari. Aneka Ilmu, Semarang.

Sudarmadji, S., B. Haryono dan Suhardi. 1984. Prosedur Analisa untuk Bahan Makanan dan Pertanian. Liberty, Yogyakarta.

Winarno, F.G. 1997. Kimia Pangan dan Gizi. P.T. Gramedia Pustaka Umum, Jakarta.

Winarno, F.G, S. Fardiaz, dan D. Fardiaz. 1980. Pengantar Teknologi Pangan. P.T. Gramedia, Jakarta. 